Chinese Journal of Organic Chemistry

\title{
高效镁催化的羧酸硼氢化反应
}

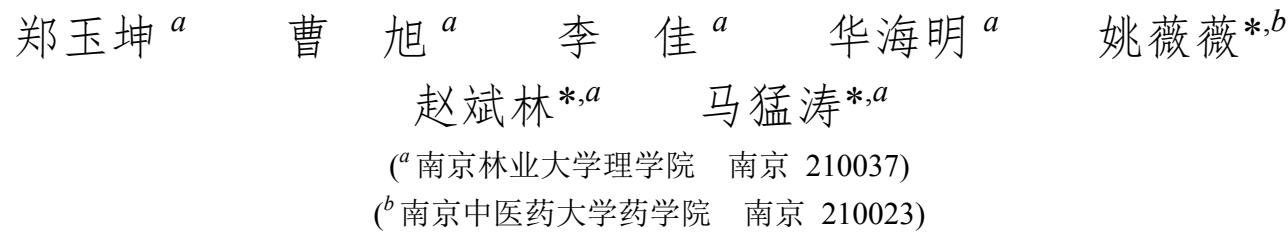

\begin{abstract}
摘要 在温和的反应条件下，较大空间位阻的氨基镁甲基化合物 $\mathrm{LMgCH}_{3}(\mathrm{THF})_{2}\left[\mathrm{~L}=\mathrm{N}(\mathrm{Ar})\left(\mathrm{SiMe}_{3}\right), \mathrm{Ar}=4,2,6-\right.$ $\left.\mathrm{Me}\left(\mathrm{CHPh}_{2}\right)_{2} \mathrm{C}_{6} \mathrm{H}_{2}\right]$, 可作为高效催化剂前体应用于一系列芳香族和脂肪族羧酸与频哪醇嗍烷的脱氧硼氢化反应中. 在 同样反应条件下观察到羧酸对酯的化学选择性嗍氢化. 基于密度函数理论(DFT)计算和化学计量反应，提出了两种可 能的羧酸硼氢化反应机理.
\end{abstract}

关键词 嗍氢化; 羧酸; 镁; 主族金属

\section{Efficient Magnesium-Catalyzed Hydroboration of Carboxylic Acids}

\author{
Zheng, Yukun ${ }^{a}$ \\ Cao, $\mathrm{Xu}^{a}$ \\ $\mathrm{Li}, \mathrm{Jia}^{a}$ \\ Hua, Haiming ${ }^{a}$ \\ Yao, Weiwei* ${ }^{*, b}$ \\ Zhao, Binlin*a \\ Ma, Mengtao*,a \\ $\left({ }^{a}\right.$ College of Science, Nanjing Forestry University, Nanjing 210037) \\ $\left({ }^{b}\right.$ College of Pharmacy, Nanjing University of Chinese Medicine, Nanjing 210023)
}

\begin{abstract}
Sterically bulky amino magnesium methyl complex, $\mathrm{LMgCH}_{3}(\mathrm{THF})_{2}\left(\mathrm{~L}=\mathrm{NAr}\left(\mathrm{SiMe}_{3}\right), \operatorname{Ar}=4,2,6-\mathrm{Me}(\mathrm{CHPh})_{2}\right.$ - $^{-}$ $\mathrm{C}_{6} \mathrm{H}_{2}$ ) has been employed as an efficient precatalyst for the deoxygenate hydroboration of a variety of aromatic and aliphatic acids with pinacolborane (HBpin) under mild reaction condition. Additionally, chemoselective hydroboration of carboxylic acids over esters was also achieved under the standard conditions. Two plausible reaction mechanisms were proposed based on the density functional theory (DFT) calculations and stoichiometric reactions.
\end{abstract}

Keywords hydroboration; carboxylic acid; magnesium; main group metal

\section{Introduction}

The reduction of carboxylic acids to alcohols is one of the very important chemical transformations in organic chemistry and a relatively difficult reaction compared to the reduction of aldehydes, ketones and esters. It is commonly performed using stoichiometric metal hydride reagents such as $\mathrm{LiAlH}_{4}$ or $\mathrm{NaBH}_{4}$ that posed an inherent safety risk and inorganic waste material due to their high reactivities. The catalytic hydrogenation of carboxylic acids required various precious transition metals that typically operated at the harsh reaction conditions (high temperatures and high pressures). ${ }^{[1-5]}$ Another method is the transition metal $(\mathrm{Ru}, \mathrm{Rh}, \mathrm{Ir}, \mathrm{Fe}, \mathrm{Mn}, \mathrm{Cu}$ etc.) catalyzed hydrosilylation of carboxylic acids to alcohols which is efficient, however, the limited substrate scope and the use of light-mediated protocols can be considered as principal drawbacks in the hydrosilylation. ${ }^{[6-13]}$ In addition, most of hydrosilylation of carboxylic acids provided aldehyde products selectively depending on the molecular structure of the substrates and the metal catalysts. ${ }^{[6-7,10-11]}$ Sometimes the aliphatic acids were over-reduced via hydrosilylation to afford the corresponding alkane derivatives. ${ }^{[13]}$

Recently the hydroboration has attracted considerable attention and showed high efficiency in the reduction of unsaturated organic compounds such as aldehyde, ketone, ester etc. ${ }^{[14-20]}$ The more efficient and facile hydroboration was a plausible alternative protocol for the reduction of carboxylic acids to alcohol products. However, examples of metal-catalyzed hydroboration of carboxylic acids are

\footnotetext{
* Corresponding authors. E-mail: yww0715@hotmail.com; zblchemistry@163.com; mengtao@njfu.edu.cn Received March 25, 2020; revised April 26, 2020; published online May 11, 2020.

Project supported by the National Natural Science Foundation of China (Nos. 21772093, 21372117) and the Natural Science Foundation of Jiangsu Province (No. BK20181421).

国家自然科学基金(Nos. 21772093, 21372117)和江苏省自然科学基金(No. BK20181421)资助项目.
} 
very rare. Gunanathan et $a l^{[21]}$ recently reported the first example of Ru-catalyzed hydroboration of carboxylic acids. Soon afterwards, Leitner and Maji et al. ${ }^{[22]}$ subsequently reported the Mn-catalyzed hydroboration of carboxylic acid, respectively. To date there is an increasing demand for green and sustainable alternative to replace transition metals catalyst. Compared to the transition metals, alkaline earth metal, especially magnesium offers earth-abundant, non-toxic, and environmentally benign properties in general. However, to the best of our knowledge, there is no example of main group metal catalyzed hydroboration of carboxylic acids in the literature. Taking into account the interest in developing new catalyst for the reduction of carboxylic acids, we herein describe an efficient and facile main group Mg-catalyzed hydroboration of carboxylic acids with HBpin under mild conditions. During this protocol, several groups reported independently the catalyst-free and solvent-free hydroboration of carboxylic acids quite recently, however, they required relatively excessive HBpin (4 equiv.) or longer reaction time $(12 \mathrm{~h}){ }^{[23]}$

\section{Results and discussion}

Initially, the hydroboration reaction of benzoic acid with 3 equiv. of HBpin was performed at $60{ }^{\circ} \mathrm{C}$ under catalyst-free and solvent-free conditions. Only 30\% yield was obtained after $1 \mathrm{~h}$ (Entry 1, Table 1). When $0.1 \mathrm{~mol} \%$ magnesium complex 1 was added, the yield was increased to $82 \%$ in $2 \mathrm{~h}$ under the same reaction condition (Entry 2, Table 1). When a slightly excessive HBpin (3.1 equiv.) was employed, benzoic acid was completely converted into the corresponding benzyl boronate ester in quantitative yield within $2 \mathrm{~h}$ (Entries 4, 5, Table 1). If without catalyst, only $40 \%$ yield was obtained (Entry 3 , Table 1 ). The low yield was observed when the similar reaction was performed at room temperature (Entry 6, Table 1). It is noteworthy that the new main group Mg-catalyzed protocol is more efficient than the corresponding transition metal $\mathrm{Ru} /$ Mn-catalyzed hydroboration of carboxylic acid (Mg: $60{ }^{\circ} \mathrm{C}, 2 \mathrm{~h}$ vs $\left.\mathrm{Ru} / \mathrm{Mn}: 60 \sim 115{ }^{\circ} \mathrm{C}, 20 \sim 24 \mathrm{~h}\right) .{ }^{[21-22]}$ Moreover, compared to catalyst-free approach, the $\mathrm{Mg}$ catalyst also offers some advantages such as less amount of HBpin or short reaction time. ${ }^{[23]}$

With the optimized reaction conditions in hand, we decide to examine the scope of deoxygenative hydroboration of carboxylic acids. As shown in Table 2, the reduction of a wide range of aromatic and aliphatic carboxylic acids proceeded very well. For example, the deoxygenative hydroboration of a series of benzoic acid derivatives with electron-donating or electron-withdrawing groups such as $\mathrm{Me},{ }^{t} \mathrm{Bu}, \mathrm{OMe}, \mathrm{F}, \mathrm{Cl}$, and $\mathrm{Br}$ were all efficiently converted into the corresponding alkyl boronate esters in high yield $(\mathbf{3 b} \sim \mathbf{3 h}$, Table 2$)$. The reactivity of para-fluoro-substituted of benzoic acid was slightly higher than that of ortho-fluoro-substituted benzoic acid (3e, 3f, Table 2). It was consistent with Ru-catalyzed hydroboration of para/ortho-
Table 1 Optimization of hydroboration of benzoic acid

$$
\text { 至 }
$$

\begin{tabular}{cccccc}
\hline Entry & $n$ & Cat. 1/mol\% & $t /{ }^{\circ} \mathrm{C}$ & Time $/ \mathrm{h}$ & Yield $^{a} / \%$ \\
\hline 1 & 3.0 & - & 60 & 1 & 30 \\
2 & 3.0 & 0.1 & 60 & 2 & 82 \\
3 & 3.1 & - & 60 & 1 & 40 \\
4 & 3.1 & 0.1 & 60 & 1 & 61 \\
5 & 3.1 & 0.1 & 60 & 2 & 99 \\
6 & 3.1 & 0.1 & 25 & 2 & 15 \\
\hline
\end{tabular}

${ }^{a}$ The yield was determined by ${ }^{1} \mathrm{H}$ NMR spectroscopy.

bromo benzoic acid ${ }^{[21]}$. Even the acetoxy group was tolerated in the hydroboration of 4-acetoxybenzoic acid and afforded $97 \%$ yield (3i, Table 2). For the hydroboration of sterically bulky carboxylic acid such as 4-tert-butyl benzoic acid, the main group magnesium catalyst $\mathbf{1}$ only required $2 \mathrm{~h}$ to obtain $99 \%$ yield. However, when the same reaction was intervened within $8 \mathrm{~h}$, the transition metal ruthenium catalyst only provided $70 \%$ yield. It needed to lengthen $24 \mathrm{~h}$ to afford 91\% yield (Mg: 99\% yield, $2 \mathrm{~h}$ vs. Ru: $70 \%$ yield, $8 \mathrm{~h}$ or $91 \%$ yield, $24 \mathrm{~h}) .{ }^{[21]}$ In contrast to iron-catalyzed hydrosilylation of carboxylic acid, which involving the electron-rich carboxylic acids such as 4-tert-butyl benzoic acid and 4-methoxy benzoic acid led to over-reduction and resulted in alkane formation, ${ }^{[11]}$ a especial reaction of benzoic acid with 4 equiv. of HBpin and $2 \mathrm{~mol} \%$ catalyst loading of 1 was carried out at an elevated temperature $\left(90{ }^{\circ} \mathrm{C}\right)$ for $24 \mathrm{~h}$. The selective formation of benzyl boronate ester was observed as an exclusive product. More sterically bulky benzoic acid derivatives such as 1-naphthoic acid and 2-naphthoic acid were also hydroborated in full conversion to the corresponding alkyl boronate esters (3j, $\mathbf{3 k}$, Table 2).

Encouraged by the excellent reactivity of $\mathbf{1}$ on the hydroboration of aromatic acids, we then extended the substrate scope to the aliphatic carboxylic acids. To our delight, the hydroboration of aliphatic carboxylic acids catalyzed by 1 was also successfully transformed to the corresponding alkyl boronate esters in excellent yields, irrespective of steric and electronic nature of the substrates. The initial hydroboration of acetic acid with HBpin proceeds rapidly to afford the ethyl boronate ester in quantitative yield (31, Table 2). However, when increasing the carbon-chain length of acetic acid such as pentanoic acid and heptanoic acid, a gradually decreased conversion of product was obtained (94\% and 93\%, respectively, 3m, 3n, Table 2). Moreover, halide-substituted aliphatic carboxylic acid (3-chloropropionic acid) was subjected to hydroboration with HBpin, and 95\% yield was observed. Similarly, 
Table 2 Hydroboration of carboxylic acids catalyzed by magnesium complex $\mathbf{1}^{a}$

$$
\begin{aligned}
& \mathrm{R} \stackrel{\mathrm{O}}{\stackrel{\mathrm{OH}}{\mathrm{O}}+3.1 \mathrm{HBpin} \frac{0.1 \mathrm{~mol} \% 1}{60^{\circ} \mathrm{C}, \text { neat }}} \mathrm{R} \widehat{\text { OBpin }}+\mathrm{O}(\text { Bpin })_{2} \\
& 2 \mathrm{~h},-\mathrm{H}_{2}
\end{aligned}
$$<smiles>COc1ccc(C(=O)O)cc1</smiles>

3a, $99 \% \quad 3 b, 98 \%$<smiles>O=C(O)c1ccc(F)cc1</smiles><smiles>O=C(O)c1ccccc1F</smiles>
3c, $99 \%$<smiles>O=C(O)c1ccc(Cl)cc1</smiles><smiles></smiles>
3f, $96 \%$<smiles>CC(=O)Oc1ccc(C(=O)O)cc1</smiles>
$3 g, 99 \%$ $3 h, 99 \%$<smiles>O=C(O)c1ccc2ccccc2c1</smiles><smiles>CC(=O)O</smiles>
$3 i, 97 \%$ 3j, 99\% 3I, $99 \%$<smiles>CCCCCC(=O)O</smiles>

$3 q, 98 \%$

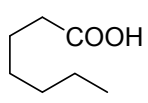

3n, 93\%<smiles>CC(C)(C)C(=O)O</smiles>

$3 r, 98 \%$<smiles>O=C(O)CCC1CCCCC1</smiles>
3o, $95 \%$<smiles>O=C(O)CCc1ccccc1</smiles>

3s, $99 \%$<smiles>O=C(O)CCCc1ccccc1</smiles>

3t, $99 \%$<smiles>CC(C(=O)O)c1ccccc1</smiles>

3u, 97\%

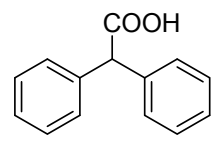

3v, $99 \%$

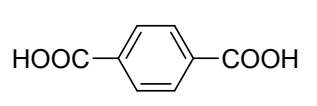

$3 w, 95 \%^{b}$

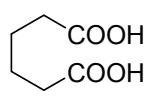

$3 \mathbf{x}, 96 \%^{b}$
${ }^{a}$ The yield was determined by ${ }^{1} \mathrm{H}$ NMR spectroscopy. ${ }^{b}$ HBpin (6.2 equiv.) was used.

hydroboration of many other aliphatic carboxylic acids, such as 2-cyclohexyl acetic acid, cyclohexanecarboxylic acid, pivalic acid, 3-phenylpropanoic acid and 4-phenylbutyric acid, have provided the corresponding boronate esters in quantitative conversion under the standard conditions (3p $\sim 3 t$, Table 2). To our surprise, the hydroboration reaction of more sterically bulky 2 -phenylpropanoic acid and diphenylacetic acid afforded high yields in the short reaction time (3u, 3v, Table 2). Furthermore, dicarboxylic acids (for instance, terephthalic acid and adipic acid) were treated with HBpin under the standard reaction conditions, the corresponding diboronate esters were also obtained in excellent conversions (3w, 3x , Table 2). Subsequently, these diboronate esters could be further hydrolyzed to diol products which are generally an important structural motif in many natural products and biological active substances. Compared with the traditional hydrogenation of diacid methods (generally involving either high temperature and pressure or low yield drawbacks) and the reported $\mathrm{Ru} / \mathrm{Mn}$ - catalyzed method, ${ }^{[21-22]}$ the Mg-catalyzed system displayed a much safer and higher efficient alternative protocol.

Based on the aforementioned excellent conversions of carboxylic acids to boronate esters, several representative boronate esters were selected to hydrolyze to afford the corresponding alcohols. The results were summarized in Table 3. Generally, the resultant boronate esters could be further hydrolyzed to the corresponding alcohols in high yields. For example, the benzoic acid (3a) was hydroborated to the benzyl boronate ester in $99 \%$ conversion, then directly hydrolyzed without separation. The corresponding benzyl alcohol (4a, Table 3) was obtained in 93\% isolated yield after workup. Other carboxylic acid derivatives such as benzoic acid with electron-withdrawing group (3e) or aliphatic carboxylic acids $(\mathbf{3 m}, \mathbf{3 q}, \mathbf{3 s})$ also provided the corresponding alcohol products $(\mathbf{4 b} \sim \mathbf{4 e}$, Table 3$)$ in very high isolated yield overall after successive hydroboration and hydrolysis. This protocol provides an efficient and mild method for the reduction of carboxylic acids to alcohols.

Table 3 Hydrolysis of selected boronate esters to alcohols

$$
\begin{aligned}
& \mathrm{R}_{\mathrm{OH}}+3.1 \mathrm{HBpin} \frac{0.1 \mathrm{~mol} \% 1}{60^{\circ} \mathrm{C}, \text { neat, } 2 \mathrm{~h}} \mathrm{R} \text { OBpin } \\
& -\mathrm{O}(\text { Bpin })_{2},-\mathrm{H}_{2} \\
& \mathrm{R} \widehat{\mathrm{OH}}
\end{aligned}
$$<smiles>CCCCC(=O)OCCCOCC1CCCCC1C(=O)O</smiles>

${ }^{a}$ The conversion was determined by ${ }^{1} \mathrm{H}$ NMR spectroscopy. ${ }^{b}$ Isolated yields.

In addition, the challenging chemoselective hydroboration of carboxylic acid with esters using 1 was explored (Scheme 1). Under the same reaction conditions, equimolar amounts of benzoic acid, methyl benzoate and 3.1 equiv. of HBpin were treated with $0.1 \mathrm{~mol} \%$ 1. It resulted in $99 \%$ conversion of benzoic acid to boronate ester in $2 \mathrm{~h}$ and the methyl benzoate remained intact as confirmed by ${ }^{1} \mathrm{H}$ NMR analysis. Similarly, the competitive intermolecular catalytic hydroboration of benzoic acid with benzyl benzoate was 
also tested, and an exclusive formation of deoxygenated boronate ester from carboxylic acid was observed. ${ }^{1} \mathrm{H}$ NMR analysis indicated the presence of more than $99 \%$ of unreacted benzyl benzoate in the reaction mixture.

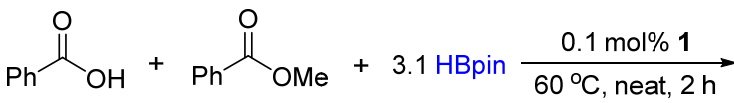

$$
\begin{aligned}
& \mathrm{Ph}_{\mathrm{OBpin}}+{ }_{\mathrm{Ph}} \stackrel{\mathrm{O}}{\mathrm{OMe}} \\
& \text { 3a, } 99 \%
\end{aligned}
$$

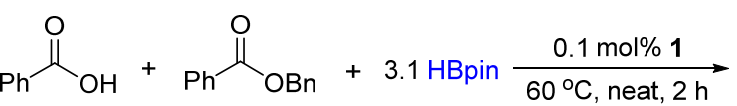

$$
\begin{aligned}
& \mathrm{Ph}_{\mathrm{OBpin}}+{ }_{\mathrm{Ph}} \stackrel{\mathrm{O}}{\mathrm{O}} \\
& \text { 3a, } 99 \%
\end{aligned}
$$

Scheme 1 Chemoselective hydroboration of carboxylic acid with esters

\subsection{Mechanism studies}

In order to gain a further understanding of the above $\mathrm{Mg}$-catalyzed hydroboration of various carboxylic acids, quantum mechanical calculations were employed to probe the profile of the reaction between acetic acid and HBpin (Figure 1). Based on the theory calculations and stoichiometric reaction experimental results, two plausible reaction mechanisms were proposed. The overall catalytic cycle of reaction consists of two steps. The first step is the formation of boryl ester (RCOOBpin) (1st step, Scheme 2). There are two possible pathways for the formation of RCOOBpin. It could be achieved from a noncatalytic reaction of carboxylic acids and HBpin with liberation of dihydrogen which has been detected and confirmed by GC analysis reported by Gunanathan et al. ${ }^{[21]}$ However, according to the density functional theory (DFT) calculation, the formation of boryl ester via the Mg-catalyzed pathway required fairly lower activation energy (9.0 vs. 51.0 $\mathrm{kcal} / \mathrm{mol}$, Figure 1). The acetic acid was firstly reacted with the magnesium hydride $(\mathrm{LMgH})$ to generate the low-energy stable magnesium acetate complex int $2 b$ $(-37.9 \mathrm{kcal} / \mathrm{mol})$, and side product dihydrogen was confirmed as gas bubble that was observed in the beginning of the reaction. The intermediate int $2 b$ was further treated with HBpin to afford the boryl ester compound with concomitant elimination of $\mathrm{LMgH}$.

The second step of catalytic cycle also has two potential pathways (2nd step, Scheme 2). For the catalytic pathway $\mathbf{A}$, the insertion of in situ generated $\mathrm{LMgH}$ species into the $\mathrm{C}=\mathrm{O}$ bond of the previously formed boryl ester leads to the formation of the magnesium alkoxy boryl ester derivative (int2d). Next, the intermediate int $2 \mathrm{~d}$ was further reacted with HBpin which underwent a proton shift from

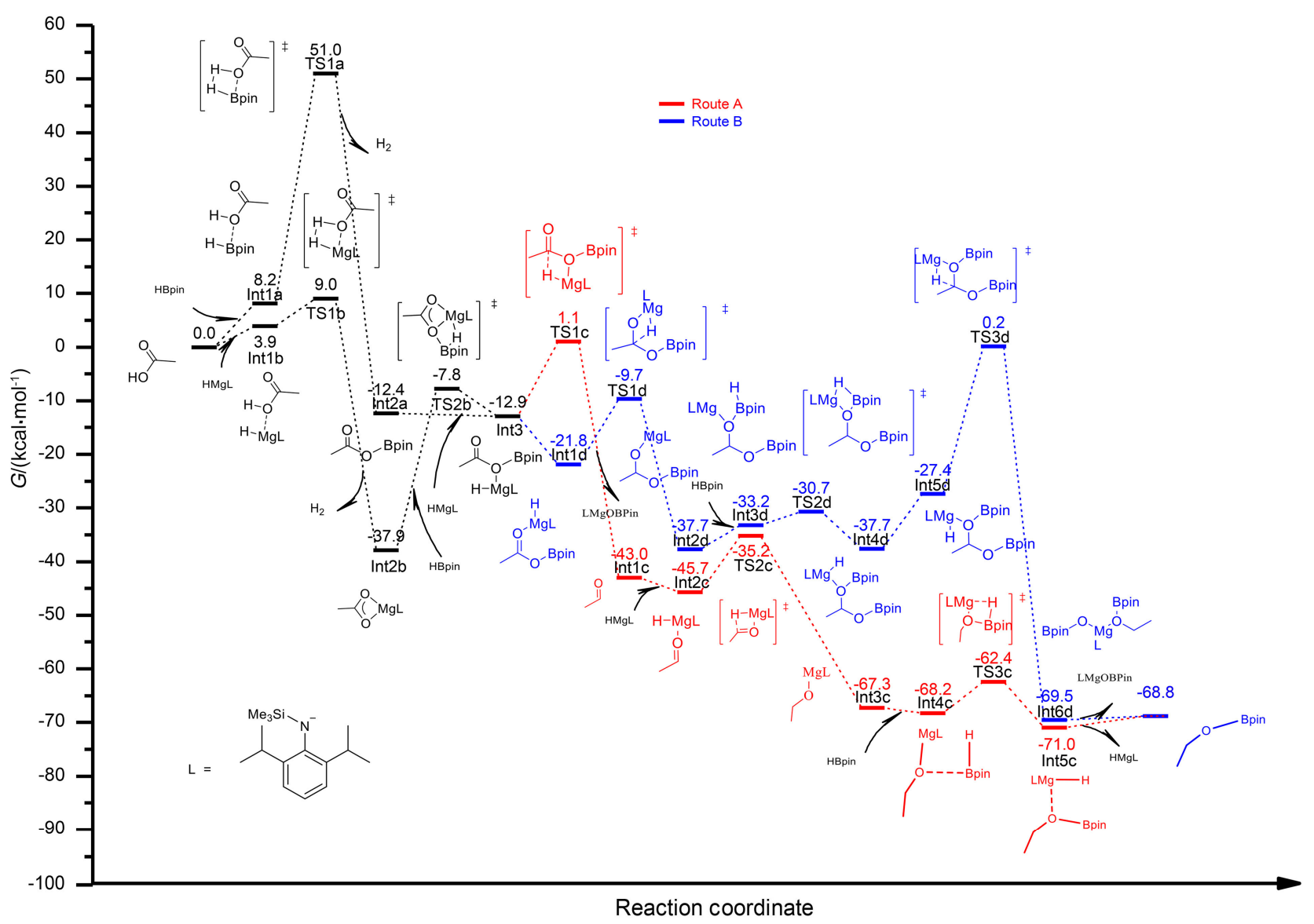

Figure 1 Calculated reaction pathway for hydroboration of carboxylic acid 

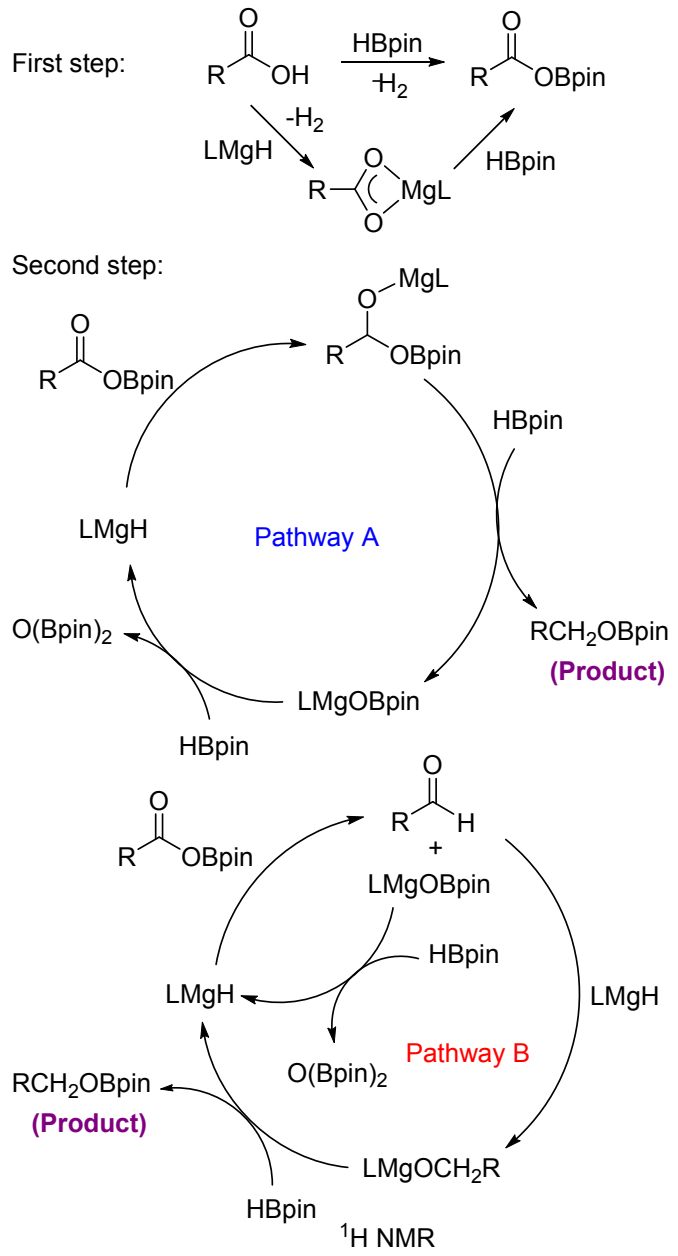

$\mathrm{R}=\mathrm{Ph}, \delta 10.04$, singlet

$\mathrm{R}={ }^{n} \mathrm{Bu}, \delta 9.73$, triplet, $J=1.8 \mathrm{~Hz}$

Scheme 2 Proposed mechanism for the Mg-catalyzed hydroboration of carboxylic acid

boron atom to carbon atom to form a $\mathrm{Mg}-\mathrm{O}-\mathrm{C}-\mathrm{H}$ four-membered ring (TS3d). The transition state TS3d decomposed spontaneously via $\mathrm{C}-\mathrm{O}$ bond cleavage due to the process is exothermic $\left(\Delta G^{\neq}=-69.7 \mathrm{kcal} / \mathrm{mol}\right)$. Finally, the alkoxyboronate ester product was obtained with the elimination of magnesium boryloxide species (LMgOBpin) that was reacted with another equivalent of HBpin to regenerate the magnesium hydride with concomitant formation of diboryl ether by-product $\mathrm{O}(\text { Bpin })_{2}$.

However, an alternative reaction pathway $\mathbf{B}$ cannot be ruled out. The first step obtained boryl ester could be coordinated to in situ generated $\mathrm{LMgH}$ species to form the $\mathrm{H}-$ $\mathrm{Mg}-\mathrm{O}-\mathrm{C}$ four-membered ring ( $\mathrm{TS} 1 \mathrm{c})$. The transition state TS1c then decomposed spontaneously into aldehyde and magnesium boryloxide species (LMgOBpin) via a C$\mathrm{O}$ bond cleavage of boryl ester due to the favorable exothermic progress $\left(\Delta G^{\ddagger}=-44.1 \mathrm{kcal} / \mathrm{mol}\right)$. LMgOBpin was treated with HBpin to regenerate the magnesium hydride with elimination of diboryl ether by-product $\mathrm{O}(\mathrm{Bpin})_{2}$ as pathway A. The benzaldehyde can be observed in the crude ${ }^{1} \mathrm{H}$ NMR spectrum of the stoichiometric reaction of benzoic acid (1 equiv.), HBpin (2 equiv.) and complex 1 (1 equiv.). The characterized $\mathrm{C}-\mathrm{H}$ proton signal of aldehyde group at $\delta 10.04$ (singlet) was observed in the corresponding ${ }^{1} \mathrm{H}$ NMR spectrum which indicated the presence of free benzaldehyde (the corresponding value is $\delta 10.03$ in the ${ }^{1} \mathrm{H}$ NMR spectrum of pure benzaldehyde). Additionally, the in situ ${ }^{1} \mathrm{H}$ NMR monitoring of the stoichiometric reaction between pentanoic acid (1 equiv.) and HBpin (2 equiv.) as well as complex 1 (1 equiv.) was also carried out. The aldehyde $\mathrm{C}-\mathrm{H}$ signal of valeraldehyde resonated at $\delta 9.73$ which was slightly different from that of the free valeraldehyde $(\delta 9.40)$ perhaps due to that the aldehyde was coordinated to the magnesium metal center and resulted in a small migration of chemical shift. However, the obtained peak type and coupling constant (triplet, ${ }^{3} J_{\mathrm{HH}}=1.8 \mathrm{~Hz}$ ) are the same to the theoretical values of free valeraldehyde. All these information suggested the appearance of valeraldehyde. The subsequent reaction pathway underwent the catalytic hydroboration of aldehyde which proceeded smoothly and reported by many research groups. The generated aldehyde was immediately reacted with the magnesium hydride to afford the magnesium alkoxyl complex which further treated with HBpin to liberate the alkoxyboronate ester product and recover $\mathrm{LMgH}$.

\section{Conclusions}

In summary, we have demonstrated that monodentate amido magnesium methyl complex $\mathbf{1}$ as the first main group catalyst has been successfully employed for the highly efficient and selective hydroboration of various carboxylic acid. The results showed that both aromatic and aliphatic carboxylic acid as well as dicarboxylic acids could be hydroborated to the respective alkyl boronate esters, and selected boronate esters were further hydrolyzed to provide the corresponding alcohols in high isolated yields. In addition, the newly developed protocol also shows high chemoselectivity for carboxylic acid over esters. DFT calculations and stoichiometric reactions indicated that there were two possible different reaction pathways in the catalytic cycle. Overall, the new protocol not only provided another more efficient and mild method than the corresponding traditional hydrogenation and hydrosilylation for the reduction of carboxylic acid to alcohols, but also showed that the main group magnesium catalyst outperformed the transition metal ruthenium and manganese catalysts for deoxygenative hydroboration of carboxylic acid. This is quite different from the general trend that the catalytic efficiency of transition metals is much better than that of main group metals in many organic reactions. The main group elements may have "transition-metallike" catalytic property or better as mentioned by Power in $2010 .{ }^{[24]}$ We will continue to explore the catalytic application of magnesium complexes.

\section{Experimental section}

\subsection{General information}

All air-sensitive compounds were carried out using 
standard Schlenk-line or glovebox techniques under highpurity argon. Diethyl ether, toluene, tetrahydrofuran (THF) and hexane were dried and distilled from molten sodium. ${ }^{1} \mathrm{H}$ NMR and ${ }^{13} \mathrm{C}$ NMR spectra were recorded at $25{ }^{\circ} \mathrm{C}$ with a Bruker Avance III $600 \mathrm{MHz}$ spectrometer and were referenced to the resonances of the solvent used. Complex 1 was prepared according to literature procedure. ${ }^{[25]}$ Other reagents were used as received.

\subsection{General procedure for catalytic hydroboration of carboxylic acids}

To a Schlenk tube carboxylic acid $(0.25 \mathrm{mmol})$, HBpin $(0.775 \mathrm{mmol})$ and $1(0.1 \mathrm{~mol} \%)$ were added in the glove box. The reaction mixture was stirred for $2 \mathrm{~h}$ at $60{ }^{\circ} \mathrm{C}$. After that, the reaction mixture was evaporated under reduced pressure (to remove unreacted HBpin) and analyzed by ${ }^{1} \mathrm{H}$ NMR and ${ }^{13} \mathrm{C}$ NMR spectra after adding $0.5 \mathrm{~mL}$ of $\mathrm{CDCl}_{3}$.

2-(Benzyloxy)-4,4,5,5-tetramethyl-1,3,2-dioxaborolane (3a): ${ }^{[23 b] ~}{ }^{1} \mathrm{H}$ NMR $\left(\mathrm{CDCl}_{3}, 600 \mathrm{MHz}\right) \delta: 1.25(\mathrm{~s}, 36 \mathrm{H}), 4.91$ (s, 2H), $7.23 \sim 7.34(\mathrm{~m}, 5 \mathrm{H}) ;{ }^{13} \mathrm{C} \mathrm{NMR}\left(\mathrm{CDCl}_{3}, 151 \mathrm{MHz}\right)$ $\delta: 24.6,24.7,66.7,83.0,83.2,126.8,127.4,128.3,139.3$.

4,4,5,5-Tetramethyl-2-((4-methylbenzyl)oxy)-1,3,2-dioxaborolane (3b): ${ }^{[23 b]}{ }^{1} \mathrm{H}$ NMR $\left(\mathrm{CDCl}_{3}, 600 \mathrm{MHz}\right) \delta: 1.25$ $(\mathrm{s}, 36 \mathrm{H}), 2.32(\mathrm{~s}, 3 \mathrm{H}), 4.87(\mathrm{~s}, 2 \mathrm{H}), 7.12(\mathrm{~d}, J=7.8 \mathrm{~Hz}$, 2H), $7.22(\mathrm{~d}, J=7.8 \mathrm{~Hz}, 2 \mathrm{H}) ;{ }^{13} \mathrm{C} \mathrm{NMR}\left(\mathrm{CDCl}_{3}, 151 \mathrm{MHz}\right)$ $\delta: 21.2,24.6,24.7,66.7,83.0,83.1,83.2,126.9,129.0$, $136.4,137.0$.

2-((4-(tert-Butyl)benzyl)oxy)-4,4,5,5-tetramethyl-1,3,2dioxaborolane (3c): $:{ }^{[23 b]}{ }^{1} \mathrm{H}$ NMR $\left(\mathrm{CDCl}_{3}, 600 \mathrm{MHz}\right) \delta$ : $1.26(\mathrm{~s}, 36 \mathrm{H}), 1.31(\mathrm{~s}, 9 \mathrm{H}), 4.89(\mathrm{~s}, 2 \mathrm{H}), 7.27(\mathrm{~d}, J=8.4$ $\mathrm{Hz}, 2 \mathrm{H}), 7.35(\mathrm{~m}, 2 \mathrm{H}) ;{ }^{13} \mathrm{C} \mathrm{NMR}\left(\mathrm{CDCl}_{3}, 151 \mathrm{MHz}\right) \delta$ : $24.57,24.61,24.7,31.5,34.6,66.6,83.0,83.2,125.3$, $126.7,136.4,150.4$.

2-((4-Methoxybenzyl)oxy)-4,4,5,5-tetramethyl-1,3,2-dioxaborolane (3d): ${ }^{[23 b]}{ }^{1} \mathrm{H}$ NMR $\left(\mathrm{CDCl}_{3}, 600 \mathrm{MHz}\right) \delta: 1.27$ $(\mathrm{s}, 36 \mathrm{H}), 3.79(\mathrm{~s}, 3 \mathrm{H}), 4.85(\mathrm{~s}, 2 \mathrm{H}), 6.86(\mathrm{~d}, J=8.4 \mathrm{~Hz}$, 2H), 7.27 (d, $J=8.4 \mathrm{~Hz}, 2 \mathrm{H}) ;{ }^{13} \mathrm{C} \mathrm{NMR}\left(\mathrm{CDCl}_{3}, 151 \mathrm{MHz}\right)$ $\delta: 24.55,24.60,24.7,55.3,66.5,83.0,83.16,83.18,113.8$, $128.6,131.6,159.1$.

2-((4-Fluorobenzyl)oxy)-4,4,5,5-tetramethyl-1,3,2-dioxaborolane (3e): ${ }^{[23 \mathrm{~b}]}{ }^{1} \mathrm{H}$ NMR $\left(\mathrm{CDCl}_{3}, 600 \mathrm{MHz}\right) \delta$ : $1.23(\mathrm{~s}$, $36 \mathrm{H}), 4.85(\mathrm{~s}, 2 \mathrm{H}), 6.98(\mathrm{t}, J=8.4 \mathrm{~Hz}, 2 \mathrm{H}), 7.29(\mathrm{~m}, 2 \mathrm{H})$; ${ }^{13} \mathrm{C} \mathrm{NMR}\left(\mathrm{CDCl}_{3}, 151 \mathrm{MHz}\right) \delta: 24.56,24.60,24.7,66.1$, $83.1,83.2,115.1,115.2,128.68,128.73,135.1,161.5$, 163.1 .

2-((2-Fluorobenzyl)oxy)-4,4,5,5-tetramethyl-1,3,2-dioxaborolane (3f): ${ }^{[23 \mathrm{~b}]}{ }^{1} \mathrm{H}$ NMR $\left(\mathrm{CDCl}_{3}, 600 \mathrm{MHz}\right) \delta$ : $1.24(\mathrm{~s}$, $36 \mathrm{H}), 4.98(\mathrm{~s}, 2 \mathrm{H}), 6.98 \sim 7.43(\mathrm{~m}, 4 \mathrm{H}) ;{ }^{13} \mathrm{C} \mathrm{NMR}\left(\mathrm{CDCl}_{3}\right.$, $151 \mathrm{MHz}) \delta$ : 24.55, 24.59, 24.64, 60.86, 60.89, 83.18, $83.19,115.0,115.1,124.02,124.04,126.4,126.5,128.87$, 128.90, 129.0, 129.1, 159.4, 161.1.

2-((4-Chlorobenzyl)oxy)-4,4,5,5-tetramethyl-1,3,2-dioxaborolane (3g): ${ }^{[23 \mathrm{~b}]}{ }^{1} \mathrm{H} \mathrm{NMR}\left(\mathrm{CDCl}_{3}, 600 \mathrm{MHz}\right) \delta: 1.27(\mathrm{~s}$, $36 \mathrm{H}), 4.88(\mathrm{~s}, 2 \mathrm{H}), 7.29(\mathrm{~m}, 4 \mathrm{H}) ;{ }^{13} \mathrm{C}$ NMR $\left(\mathrm{CDCl}_{3}, 151\right.$ $\mathrm{MHz}) \delta: 24.55,24.60,24.7,66.0,83.2,128.2,128.5$, 133.2, 137.8 .
2-((2-Bromobenzyl)oxy)-4,4,5,5-tetramethyl-1,3,2-dioxaborolane (3h): ${ }^{[23 \mathrm{~b}]}{ }^{1} \mathrm{H}$ NMR $\left(\mathrm{CDCl}_{3}, 600 \mathrm{MHz}\right) \delta: 1.25$ (s, $36 \mathrm{H}), 4.96(\mathrm{~s}, 2 \mathrm{H}), 7.11 \sim 7.49(\mathrm{~m}, 4 \mathrm{H}, \mathrm{ArH}) ;{ }^{13} \mathrm{C} \mathrm{NMR}$ $\left(\mathrm{CDCl}_{3}, 151 \mathrm{MHz}\right) \delta: 24.57,24.61,24.7,66.4,83.16$, 83.18, 83.23, 121.6, 127.4, 127.9, 128.7, 132.3, 138.4.

4-(((4,4,5,5-Tetramethyl-1,3,2-dioxaborolan-2-yl)oxy)methyl)phenyl acetate (3i): ${ }^{[23 b]}{ }^{1} \mathrm{H} \mathrm{NMR}\left(\mathrm{CDCl}_{3}, 600 \mathrm{MHz}\right)$ $\delta: 1.24(\mathrm{~s}, 36 \mathrm{H}), 2.26(\mathrm{~s}, 3 \mathrm{H}), 4.88(\mathrm{~s}, 2 \mathrm{H}), 7.02(\mathrm{~m}, 2 \mathrm{H})$, $7.33(\mathrm{~d}, J=8.4 \mathrm{~Hz}, 2 \mathrm{H}) ;{ }^{13} \mathrm{C} \mathrm{NMR}\left(\mathrm{CDCl}_{3}, 151 \mathrm{MHz}\right) \delta$ : 21.1, 24.6, 24.7, 66.1, 83.05, 83.12, 121.4, 127.8, 136.9, $150.0,169.5$.

4,4,5,5-Tetramethyl-2-(naphthalen-1-ylmethoxy)-1,3,2dioxaborolane (3j): ${ }^{[23 \mathrm{~b}]}{ }^{1} \mathrm{H}$ NMR $\left(\mathrm{CDCl}_{3}, 600 \mathrm{MHz}\right) \delta: 1.27$ $(\mathrm{s}, 36 \mathrm{H}), 5.41(\mathrm{~s}, 2 \mathrm{H}), 7.43 \sim 8.05(\mathrm{~m}, 7 \mathrm{H}) ;{ }^{13} \mathrm{C} \mathrm{NMR}$ $\left(\mathrm{CDCl}_{3}, 151 \mathrm{MHz}\right) \delta: 24.6,24.7,65.1,83.1,83.2,123.6$, $125.0,125.4,125.7,126.2,128.2,128.6,131.1,133.7$, 134.8 .

4,4,5,5-Tetramethyl-2-(naphthalen-2-ylmethoxy)-1,3,2dioxaborolane (3k): ${ }^{[23 \mathrm{~b}]}{ }^{1} \mathrm{H}$ NMR $\left(\mathrm{CDCl}_{3}, 600 \mathrm{MHz}\right) \delta$ : $1.27(\mathrm{~s}, 36 \mathrm{H}), 5.10(\mathrm{~s}, 2 \mathrm{H}), 7.45(\mathrm{~m}, 3 \mathrm{H}), 7.81(\mathrm{~m}, 4 \mathrm{H}) ;{ }^{13} \mathrm{C}$ NMR $\left(\mathrm{CDCl}_{3}, 151 \mathrm{MHz}\right) \delta: 24.60,24.63,24.7,66.9,83.1$, $83.2,125.0,125.3,125.8,126.1,127.7,128.0,128.1$, 133.0, 133.4, 136.8 .

2-Ethoxy-4,4,5,5-tetramethyl-1,3,2-dioxaborolane (3I): ${ }^{[23 \mathrm{~b}]}{ }^{1} \mathrm{H}$ NMR $\left(\mathrm{CDCl}_{3}, 600 \mathrm{MHz}\right) \delta: 1.19(\mathrm{t}, J=7.2 \mathrm{~Hz}$, $3 \mathrm{H}), 1.23(\mathrm{~s}, 36 \mathrm{H}), 3.86(\mathrm{q}, J=7.2 \mathrm{~Hz}, 2 \mathrm{H}) ;{ }^{13} \mathrm{C} \mathrm{NMR}$ $\left(\mathrm{CDCl}_{3}, 151 \mathrm{MHz}\right) \delta: 17.3,24.6,24.7,60.7,82.7,83.1$.

2-(Hexyloxy)-4,4,5,5-tetramethyl-1,3,2-dioxaborolane (3m): $:{ }^{23 \mathrm{~b}]}{ }^{1} \mathrm{H}$ NMR $\left(\mathrm{CDCl}_{3}, 600 \mathrm{MHz}\right) \delta: 0.84(\mathrm{t}, J=7.2$ $\mathrm{Hz}, 3 \mathrm{H}), 1.21(\mathrm{~s}, 36 \mathrm{H}), 1.27 \sim 1.28(\mathrm{~m}, 4 \mathrm{H}), 1.49 \sim 1.54$ $(\mathrm{m}, 2 \mathrm{H}), 3.78(\mathrm{t}, J=6.6 \mathrm{~Hz}, 2 \mathrm{H}) ;{ }^{13} \mathrm{C} \mathrm{NMR}\left(\mathrm{CDCl}_{3}, 151\right.$ $\mathrm{MHz}) \delta: 14.1,22.4,24.58,24.62,27.8,31.2,65.0,82.6$, 83.2 .

4,4,5,5-Tetramethyl-2-(octyloxy)-1,3,2-dioxaborolane (3n): ${ }^{[23 \mathrm{~b}] ~}{ }^{1} \mathrm{H} \mathrm{NMR}\left(\mathrm{CDCl}_{3}, 600 \mathrm{MHz}\right) \delta: 0.84(\mathrm{t}, J=7.2 \mathrm{~Hz}$, $3 \mathrm{H}), 1.22(\mathrm{~s}, 36 \mathrm{H}), 1.28 \sim 1.30(\mathrm{~m}, 6 \mathrm{H}), 1.50 \sim 1.54(\mathrm{~m}$, $2 \mathrm{H}), 3.79$ (t, $J=6.6 \mathrm{~Hz}, 2 \mathrm{H}) ;{ }^{13} \mathrm{C} \mathrm{NMR}\left(\mathrm{CDCl}_{3}, 151 \mathrm{MHz}\right)$ $\delta: 14.1,22.7,24.55,24.58,24.62,25.6,29.0,31.5,31.9$, $65.0,82.7,83.2$.

2-(4-Chlorobutoxy)-4,4,5,5-tetramethyl-1,3,2-dioxaborolane (3o): ${ }^{[23 \mathrm{~b}]}{ }^{1} \mathrm{H}$ NMR $\left(\mathrm{CDCl}_{3}, 600 \mathrm{MHz}\right) \delta: 1.22(\mathrm{~s}$, $36 \mathrm{H}), 1.98(\mathrm{~m}, 2 \mathrm{H}), 3.60(\mathrm{t}, J=6.0 \mathrm{~Hz}, 2 \mathrm{H}), 3.96(\mathrm{t}, J=5.4$ $\mathrm{Hz}, 2 \mathrm{H}) ;{ }^{13} \mathrm{C} \mathrm{NMR}\left(\mathrm{CDCl}_{3}, 151 \mathrm{MHz}\right) \delta: 24.6,24.7,34.3$, 41.4, 61.6, 82.95, 83.04, 83.1.

2-(2-Cyclohexylethoxy)-4,4,5,5-tetramethyl-1,3,2-dioxaborolane (3p): ${ }^{[23 \mathrm{~b}]}{ }^{1} \mathrm{H}$ NMR $\left(\mathrm{CDCl}_{3}, 600 \mathrm{MHz}\right) \delta$ : $0.87 \sim$ $0.90(\mathrm{~m}, 2 \mathrm{H}), 1.10 \sim 1.16(\mathrm{~m}, 3 \mathrm{H}), 1.24(\mathrm{~s}, 36 \mathrm{H}), 1.40 \sim$ $1.43(\mathrm{~m}, 3 \mathrm{H}), 1.59 \sim 1.70(\mathrm{~m}, 5 \mathrm{H}), 3.85(\mathrm{t}, J=6.6 \mathrm{~Hz}, 2 \mathrm{H})$; ${ }^{13} \mathrm{C} \mathrm{NMR}\left(\mathrm{CDCl}_{3}, 151 \mathrm{MHz}\right) \delta: 24.6,24.7,26.4,26.7$, 33.3, 34.0, 39.0, 62.9, 82.7, 83.2.

2-(Cyclohexylmethoxy)-4,4,5,5-tetramethyl-1,3,2-dioxaborolane (3q): ${ }^{[23 \mathrm{~b}]}{ }^{1} \mathrm{H} \mathrm{NMR}\left(\mathrm{CDCl}_{3}, 600 \mathrm{MHz}\right) \delta: 0.89 \sim$ $0.94(\mathrm{~m}, 2 \mathrm{H}), 1.10 \sim 1.13(\mathrm{~m}, 3 \mathrm{H}), 1.23(\mathrm{~s}, 36 \mathrm{H}), 1.46 \sim$ $1.50(\mathrm{~m}, 1 \mathrm{H}), 1.60 \sim 1.70(\mathrm{~m}, 5 \mathrm{H}), 3.61(\mathrm{~d}, J=6.6 \mathrm{~Hz}$, $2 \mathrm{H}) ;{ }^{13} \mathrm{C} \mathrm{NMR}\left(\mathrm{CDCl}_{3}, 151 \mathrm{MHz}\right) \delta: 24.55,24.59,24.62$, 25.9, 26.6, 29.4, 39.4, 70.4, 82.7, 83.16, 83.18.

4,4,5,5-Tetramethyl-2-(neopentyloxy)-1,3,2-dioxaboro- 
lane (3r): ${ }^{[23 \mathrm{~b}]}{ }^{1} \mathrm{H} \mathrm{NMR}\left(\mathrm{CDCl}_{3}, 600 \mathrm{MHz}\right) \delta: 0.86(\mathrm{~s}, 9 \mathrm{H})$, 1.24 (s, 36H), $3.48(\mathrm{~s}, 2 \mathrm{H}) ;{ }^{13} \mathrm{C} \mathrm{NMR}\left(\mathrm{CDCl}_{3}, 151 \mathrm{MHz}\right) \delta$ : $24.58,24.62,26.1,32.4,75.0,82.7,83.2$.

4,4,5,5-Tetramethyl-2-(3-phenylpropoxy)-1,3,2-dioxaborolane (3s): ${ }^{[23 \mathrm{~b}]}{ }^{1} \mathrm{H}$ NMR $\left(\mathrm{CDCl}_{3}, 600 \mathrm{MHz}\right) \delta$ : 1.28 (s, $36 \mathrm{H}), 1.87 \sim 1.92(\mathrm{~m}, 2 \mathrm{H}), 2.70(\mathrm{t}, J=7.8 \mathrm{~Hz}, 2 \mathrm{H}), 3.88(\mathrm{t}$, $J=6.0 \mathrm{~Hz}, 2 \mathrm{H}), 7.17 \sim 7.29(\mathrm{~m}, 5 \mathrm{H}) ;{ }^{13} \mathrm{C} \mathrm{NMR}\left(\mathrm{CDCl}_{3}\right.$, $151 \mathrm{MHz}) \delta: 24.55,24.60,24.7,32.0,33.2,64.2,82.8$, $83.2,125.8,128.4,128.5,141.9$.

4,4,5,5-Tetramethyl-2-(4-phenylbutoxy)-1,3,2-dioxaborolane (3t): $:^{[23 b]}{ }^{1} \mathrm{H}$ NMR $\left(\mathrm{CDCl}_{3}, 600 \mathrm{MHz}\right) \delta$ : $1.28(\mathrm{~s}$, $36 \mathrm{H}), 1.60 \sim 1.73(\mathrm{~m}, 4 \mathrm{H}), 2.64(\mathrm{t}, J=7.8 \mathrm{~Hz}, 2 \mathrm{H}), 3.88(\mathrm{t}$, $J=6.0 \mathrm{~Hz}, 2 \mathrm{H}), 7.16 \sim 7.28(\mathrm{~m}, 5 \mathrm{H}) ;{ }^{13} \mathrm{C} \mathrm{NMR}\left(\mathrm{CDCl}_{3}\right.$, $151 \mathrm{MHz}) \delta: 24.57,24.60,24.64,27.5,31.1,35.6,64.8$, $82.7,83.13,83.17,125.7,128.3,128.5,142.5$.

4,4,5,5-Tetramethyl-2-(2-phenylpropoxy)-1,3,2-dioxaborolane $(3 \mathbf{u}):{ }^{[23 \mathrm{~b}]}{ }^{1} \mathrm{H} \mathrm{NMR}\left(\mathrm{CDCl}_{3}, 600 \mathrm{MHz}\right) \delta$ : $1.17(\mathrm{~s}$, $12 \mathrm{H}), 1.25$ (s, 24H), 1.27 (d, J=7.2 Hz, 3H), 2.93 2.99 $(\mathrm{m}, 1 \mathrm{H}), 3.84 \sim 3.97(\mathrm{~m}, 2 \mathrm{H}), 7.16 \sim 7.31(\mathrm{~m}, 5 \mathrm{H}) ;{ }^{13} \mathrm{C}$ NMR $\left(\mathrm{CDCl}_{3}, 151 \mathrm{MHz}\right) \delta: 17.6,24.53,24.56,41.4,70.4$, $82.7,83.09,83.14,126.4,127.6,128.3,143.8$.

2-(2,2-Diphenylethoxy)-4,4,5,5-tetramethyl-1,3,2-dioxaborolane (3v): ${ }^{[23 \mathrm{~b}]}{ }^{1} \mathrm{H} \mathrm{NMR}\left(\mathrm{CDCl}_{3}, 600 \mathrm{MHz}\right) \delta$ : 1.15 (s, $12 \mathrm{H}), 1.27(\mathrm{~s}, 24 \mathrm{H}), 4.24(\mathrm{t}, J=7.2 \mathrm{~Hz}, 1 \mathrm{H}), 4.41(\mathrm{~d}, J=$ $6.6 \mathrm{~Hz}, 2 \mathrm{H}), 7.17 \sim 7.28(\mathrm{~m}, 10 \mathrm{H}) ;{ }^{13} \mathrm{C} \mathrm{NMR}\left(\mathrm{CDCl}_{3}, 151\right.$ $\mathrm{MHz}) \delta: 24.53,24.55,24.58,52.6,67.9,82.7,83.05$, $83.13,126.5,128.4,128.5,141.8$.

1,4-Bis(((4,4,5,5-tetramethyl-1,3,2-dioxaborolan-2-yl)oxy)methyl)benzene (3w): ${ }^{[23 \mathrm{~b}]}{ }^{1} \mathrm{H}$ NMR $\left(\mathrm{CDCl}_{3}, 600 \mathrm{MHz}\right)$ $\delta: 1.24(\mathrm{~s}, 72 \mathrm{H}), 4.88(\mathrm{~s}, 4 \mathrm{H}), 7.28(\mathrm{~s}, 4 \mathrm{H}) ;{ }^{13} \mathrm{C} \mathrm{NMR}$ $\left(\mathrm{CDCl}_{3}, 151 \mathrm{MHz}\right) \delta: 24.61,24.67,66.6,83.0,83.1,126.8$, 138.5 .

1,6-Bis((4,4,5,5-tetramethyl-1,3,2-dioxaborolan-2-yl)oxy)hexane (3x): ${ }^{[23 \mathrm{~b}]}{ }^{1} \mathrm{H} \mathrm{NMR}\left(\mathrm{CDCl}_{3}, 600 \mathrm{MHz}\right) \delta$ : 1.19 $(\mathrm{s}, 72 \mathrm{H}), 1.29 \sim 1.30(\mathrm{~m}, 4 \mathrm{H}), 1.48 \sim 1.51(\mathrm{~m}, 4 \mathrm{H}), 3.76(\mathrm{t}$, $J=6.6 \mathrm{~Hz}, 4 \mathrm{H}) .{ }^{13} \mathrm{C} \mathrm{NMR}\left(\mathrm{CDCl}_{3}, 151 \mathrm{MHz}\right) \delta: 24.5,24.6$, 25.3, 31.4, 64.8, 82.6, 83.1.

\subsection{General procedure for hydrolysis of boronate esters to alcohols}

Upon completion of the hydroboration reaction, the resultant boronate ester was purified by column chromatography over silica-gel using ethyl acetate/hexane $(V: V=$ $1: 10)$ mixture as eluents to obtain the corresponding pure primary alcohols.

Phenylmethanol (4a): ${ }^{[21]}{ }^{1} \mathrm{H}$ NMR $\left(\mathrm{CDCl}_{3}, 600 \mathrm{MHz}\right) \delta$ : $2.75(\mathrm{~s}, 1 \mathrm{H}), 4.62(\mathrm{~s}, 2 \mathrm{H}), 7.30 \sim 7.38(\mathrm{~m}, 5 \mathrm{H}) ;{ }^{13} \mathrm{C} \mathrm{NMR}$ $\left(151 \mathrm{MHz}, \mathrm{CDCl}_{3}\right) \delta: 65.1,127.1,127.6,128.6,140.9$.

(4-Fluorophenyl)methanol (4b): ${ }^{[21]}{ }^{1} \mathrm{H}$ NMR $\left(\mathrm{CDCl}_{3}\right.$, $600 \mathrm{MHz}) \delta: 2.55(\mathrm{~s}, 1 \mathrm{H}), 4.58(\mathrm{~s}, 2 \mathrm{H}), 7.00 \sim 7.03(\mathrm{~m}$, $2 \mathrm{H}), 7.27 \sim 7.29(\mathrm{~m}, 2 \mathrm{H}) ;{ }^{13} \mathrm{C} \mathrm{NMR}\left(\mathrm{CDCl}_{3}, 151 \mathrm{MHz}\right) \delta$ : $64.5,115.3,115.5,128.8,128.9,136.61,136.63,161.5$, 163.2.

Pentan-1-ol (4c): ${ }^{[21]}{ }^{1} \mathrm{H}$ NMR $\left(\mathrm{CDCl}_{3}, 600 \mathrm{MHz}\right) \delta: 0.90$ $(\mathrm{t}, J=7.2 \mathrm{~Hz}, 3 \mathrm{H}), 1.31 \sim 1.33(\mathrm{~m}, 4 \mathrm{H}), 1.55(\mathrm{~s}, 2 \mathrm{H}), 2.01$ $(\mathrm{s}, 1 \mathrm{H}), 3.60 \sim 3.63(\mathrm{~m}, 2 \mathrm{H}) ;{ }^{13} \mathrm{C} \mathrm{NMR}\left(\mathrm{CDCl}_{3}, 151 \mathrm{MHz}\right)$ $\delta: 14.1,22.6,28.0,32.5,63.0$.
Cyclohexylmethanol (4d): ${ }^{[21]}{ }^{1} \mathrm{H}$ NMR $\left(\mathrm{CDCl}_{3}, 600\right.$ $\mathrm{MHz}) \delta: 0.85 \sim 0.92(\mathrm{~m}, 2 \mathrm{H}), 1.10 \sim 1.25(\mathrm{~m}, 3 \mathrm{H}), 1.43 \sim$ $1.44(\mathrm{~m}, 1 \mathrm{H}), 1.63 \sim 1.73(\mathrm{~m}, 5 \mathrm{H}), 2.15(\mathrm{~s}, 1 \mathrm{H}), 3.39(\mathrm{dd}$, $J=1.62 \mathrm{~Hz}, J=6.48 \mathrm{~Hz}, 2 \mathrm{H}) ;{ }^{13} \mathrm{C} \mathrm{NMR}\left(\mathrm{CDCl}_{3}, 151\right.$ MHz) $\delta: 25.9,26.7,29.7,40.5,68.7$.

3-Phenylpropan-1-ol (4e): ${ }^{[21]}{ }^{1} \mathrm{H}$ NMR $\left(\mathrm{CDCl}_{3}, 600\right.$ $\mathrm{MHz}) \delta: 1.91 \sim 1.96(\mathrm{~m}, 2 \mathrm{H}), 2.75(\mathrm{t}, J=7.8 \mathrm{~Hz}, 2 \mathrm{H}), 2.83$ $(\mathrm{s}, 1 \mathrm{H}), 3.69(\mathrm{t}, J=6.6 \mathrm{~Hz}, 2 \mathrm{H}), 7.24 \sim 7.35(\mathrm{~m}, 5 \mathrm{H}) ;{ }^{13} \mathrm{C}$ NMR $\left(\mathrm{CDCl}_{3}, 151 \mathrm{MHz}\right) \delta$ : 32.1, 34.2, 62.0, 125.8, $128.38,128.43,141.9$.

Supporting Information NMR spectroscopic spectra, chemoselective hydroboration, stoichiometric reaction, and computational studies. The Supporting Information is available free of charge via the Internet at http://sioc-journal. $\mathrm{cn} /$.

\section{References}

[1] Ullrich, J.; Breit, B. ACS Catal. 2018, 8, 785.

[2] Korstanje, T. J.; Vlugt, J. I.; Elsevier, C. J.; de Bruin, B. Science 2015, 350, 298.

[3] Cui, X.; Li, Y.; Topf, C.; Junge, K.; Beller, M. Angew. Chem., Int Ed. 2015, 54, 10596.

[4] Stein, T.; Meuresch, M.; Limper, D.; Schmitz, M.; Holscher, M.; Coetzee, J.; Cole-Hamilton, D. J.; Klankermayer, J.; Leitner, W. J. Am. Chem. Soc. 2014, 136, 13217.

[5] Brewster, T. P.; Miller, A. J. M.; Heinekey, D. M.; Goldberg, K. I. J. Am. Chem. Soc. 2013, 135, 16022.

[6] Zhang, M.; Li, N.; Tao, X.; Ruzi, R.; Yu, S.; Zhu, C. Chem. Commun. 2017, 53, 10228 .

[7] Corre, Y.; Rysak, V.; Trivelli, X.; Agbossou-Niedercorn, F.; Michon, C. Eur. J. Org. Chem. 2017, 4820.

[8] Nguyen, T. V. Q.; Yoo, W. J.; Kobayashi, S. Adv. Synth. Catal. 2016, 358, 452.

[9] Fernandez-Salas, J. A.; Manzini, S.; Nolan, S. P. Adv. Synth. Catal. 2014, 356, 308.

[10] Zheng, J.; Chevance, S.; Darcel, C.; Sortais, J. B. Chem. Commun. 2013, 49, 10010 .

[11] Misal Castro, L. C.; Li, H.; Sortais, J. B.; Darcel, C. Chem. Commun. 2012, 48, 10514.

[12] Matsubara, K.; Iura, T.; Maki, T.; Nagashima, H. J. Org. Chem. 2002, 67, 4985.

[13] Gevorgyan, V.; Rubin, M.; Liu, J. X.; Yamamoto, Y. J. Org. Chem. 2001, 66, 1672.

[14] Chong, C. C.; Kinjo, R. ACS Catal. 2015, 5, 3238.

[15] Bismuto, A.; Cowley, M. J.; Thomas, S. P. ACS Catal. 2018, 8, 2001.

[16] Das, U. K.; Higman, C. S.; Gabidullin, B.; Hein, J. E.; Baker, R. T. ACS Catal. 2018, 8, 1076.

[17] Weidner, V. L.; Barger, C. J.; Delferro, M.; Lohr, T. L.; Marks, T. J. ACS Catal. 2017, 7, 1244.

[18] Barman, M. K.; Baishya, A.; Nembenna, S. Dalton Trans. 2017, 46, 4152.

[19] Lortie, J. L.; Dudding, T.; Gabidullin, B. M.; Nikonov, G. I. ACS Catal. 2017, 7, 8454 .

[20] (a) Li, Y.; Cheng, Y.; Shan, C.; Zhang, J.; Xu, D.; Bai, R.; Qu, L.; Lan, Y. Chin. J. Org. Chem. 2018, 38, 1885 (in Chinese). (李园园，程玉华，单春晖，张敬，徐冬冬，白若鹏，屈凌波，蓝 宇, 有机化学, 2018, 38, 1885.)

(b) Wang, L.; Sun, W.; Liu, C. Chin. J. Catal. 2018, 39, 1725.

(c) He, Z.; Zhu, Q.; Hu, X.; Wang, L.; Xia, C.; Liu, C. Org. Chem. Front. 2019, 6, 900.

(d) Xuan, Q.; Song, Q. Org. Lett. 2016, 18, 4250.

(e) Luo, M.; Zang, S.; Yao, W.; Zheng, J.; Ma, M. Sci. Sin. Chim. 
2020, 50, 639.

[21] Kishan, S.; KrishnaKumar, V.; Gunanathan, C. ACS Catal. 2018, 8, 4772.

[22] (a) Erken, C.; Kaithal, A.; Sen, S.; Weyhermüller, T.; Hölscher, M.; Werlé, C.; Leitner, W. Nat. Commun. 2018, 9, 4521.

(b) Barman, M. K.; Das, K.; Maji, B. J. Org. Chem. 2019, 84, 1570.

[23] (a) Harinath, A.; Bhattacharjee, J.; Panda, T. K. Chem. Commun. 2019, 55, 1386. (b) Wang, W.; Luo, M.; Zhu, D.; Yao, W.; Xu, L.; Ma, M. Org. Biomol. Chem. 2019, 17, 3604.

(c) Xu, X.; Yan, D.; Zhu, Z.; Kang, Z.; Yao, Y.; Shen, Q.; Xue, M. ACS Omega. 2019, 4, 6775.

[24] Power, P. P. Nature 2010, 463, 171

[25] Ma, M.; Li, J.; Shen, X.; Yu, Z.; Yao, W.; Pullarkat, S. A. RSC Adv. 2017, 7, 45401 .

(Li, L.; Fan, Y.) 